\title{
Uma leitura do testemunho e do trauma em Combateremos a sombra, de Lídia Jorge, Eu sou a árvore, de Possidônio Cachapa e A última canção da noite, de Francisco Camacho
}

\section{A reading of testimony and trauma in Combateremos a Sombra (Fighting the Shadow), by Lídia Jorge, Eu Sou a Árvore (I am a Tree), by Possidônio Cachapa, and A Última Canção da Noite (The Last Sons of the Night), by Francisco Camacho}

Possui mestrado em Letras - concentração em Teoria da Literatura, com ênfase emLiteratura Portuguesa, pela Pontificia Universidade Católica do Rio Grande do Sul (1999) e doutorado em Grande do Sul (2004). Atualmente é professorassociado da Universidade Federal do Rio Grande (FURG). Tem experiência na área de Letras, com linha de pesquisa em Literatura Portuguesa e Literaturas Africanas de Lingua Portuguesa, investigando teorias que abordam a relaça

$002-4257-4892$

E-mail: ilaf@vetorial.net
José Luís Giovanoni Fornos Universidade Federal do Rio Grande (FURG). Rio Grande, RS, Brasil.

RESUMO: 0 presente ensaio examina as obras de três escritores portugueses, considerando as relações entre memória e história, numa perspectiva do testemunho e do trauma. As obras investigadas são: Eu sou a árvore, de Possidônio Cachapa, $A$ última canção da noite, de Francisco Camacho e Combateremos a sombra, de Lídia Jorge. Para tal empreendimento analítico, recorre-se aos campos teóricos da historiografia, da psicanálise e da teoria da literatura, inserindo-os numa perspectiva política e sociológica. Dos entrelaçamentos previstos, são importantes a compreensão e a explicação dos processos sociais envolvendo sujeitos vinculados em distintos territórios. Entre os estudiosos que servem de base para o estudo, estão Paul Ricoeur, Freud e Márcio Seligmann-Silva.

Palavras-chave: Memória; Testemunho; Trauma; Romance português contemporâneo.

ABSTRACT: This essay examines the works of three Portuguese writers by drawing on the relationship between memory and history, based on testimony and trauma issues. The works investigated are: Combateremos a sombra (Fighting the shadow), by Lídia Jorge, Eusou a árvore (I am a tree), by Possidônio Cachapa, and A última canção da noite (The last song of the night), by Francisco Camacho. For such an analytical enterprise, the theoretical fields of historiography, psychoanalysis, and literary theory are used, from political and sociological perspectives. Regarding the expected interweaving, it is important to understand and explain the social processes involving subjects linked in different territories. Scholars underlying this study include Paul Ricoeur, Freud, and Márcio Seligmann-Silva.

Keywords: Memory; Testimony; Trauma; Contemporary Portuguese novel. 
O presente ensaio deriva de reflexões efetuadas a partir do projeto de pesquisa "As relações entre memória e história: uma perspectiva do testemunho, do trauma e da melancolia em romances portugueses do século XXI". O objetivo do mesmo é investigar os romances portugueses publicados a partir do ano 2000 com base nas categorias acima indicadas. Tal recorte se deve, em parte, à presença de jovens escritores como, por exemplo, Gonçalo Tavares, Valter Hugo Mãe, Afonso Cruz, João Tordo, José Luís Peixoto, Patrícia Reis, Nuno Camarneiro, Jorge Reis-Sá, Paulo Varela Gomes, Francisco Camacho, Possidônio Cachapa, Bruno Vieira Amaral, entre outros, que vem se destacando, bem como aqueles já consolidados, em especial, António Lobo Antunes, José Saramago, Lídia Jorge, Teolinda Gersão, Helder Macedo, Mário Cláudio, entre outros. Em comum ao grupo ressalta-se a quantidade expressiva de publicações com respectivas premiações. 0 referencial teórico da proposta do projeto é interdisciplinar, envolvendo o diálogo da literatura com outras áreas das ciências humanas. Entre os estudiosos elencados ${ }^{1}$, destaque para Paul Ricoeur que se propõe a discutir as aporias da história e da memória. Um dos postulados do filósofo francês é compreender e oferecer "solução ao problema das relações entre o conhecimento e a prática da história e a experiência da memória viva” (RICOEUR, 2007, p. 146).

No decorrer do seu estudo A memória, a história, o esquecimento (2007), o autor evidencia a importância da memória. Ainda que a operação historiográfica se constitua em tarefa necessária na ampliação, complementação, correção, e até mesmo na refutação dos testemunhos orais e dos rastros memorialísticos, a memória aparece como guardiã última do que chama de "dialética constitutiva da preteridade do passado" (RICOEUR,

\footnotetext{
${ }^{1}$ Entre os estudiosos que servem de base para o estudo, encontram-se os trabalhos de Nietzsche, Walter Benjamin, T. H. Adorno, Emmanuel Lévinas, Jacques Derrida, Hannah Arendt, Sigmund Freud, Jacques Lacan Pau Ricoeur, Jum Lacan, Paul H. Adoro Said, HomiBhabha,
Silva, entre outros.
}

2007, p.505). Se dos acontecimentos não mais existentes, assinalados pela abolição, pode-se dizer que de fato estão acabados e ultrapassados, de outro modo, não se pode escapar de que tenham ocorridos, tomados pela ideia do tendo-sido, isto é, por trazerem em si um caráter originário e indestrutível ${ }^{2}$. Tal relação dialética entre o não-mais e o tendo-sido revela-se em momento fundamental quando se tomam acontecimentos traumáticos, já que esses não se alicerçam somente na crença, mas se fazem das imagens do passado e do seu testemunho.

O trabalho desenvolvido por Ricoeur em torno das categorias da memória, da história e do esquecimento procura responder aos grandes crimes do século XX, dentre os quais a Shoah. Com base neles, pensa a ideia de perdão e como acioná-la diante do horror proporcionado pelos genocídios. Para tanto, discorre longamente acerca da categoria memória e sua importância na constituição da operação historiográfica. Ao fazê-lo, traz o pensamento filosófico desde as concepções gregas acerca do tema, em especial, Platão e Aristóteles, passando pela tradição do olhar interior, com Santo Agostinho, John Locke, fixando em boa parte do seu estudo, na fenomenologia Husserliana em que discorre sobre os conceitos de retenção/percepção primária e secundária. Procura igualmente pensar a memória enquanto sintoma neurológico e ético-político, mostrando seus usos e abusos.

Na sequência do estudo, volta-se para o olhar exterior da memória quando recorre ao pensamento de Maurice Halbwachs que expõe o caráter coletivo da memória. Para lembrarmos, precisa-se necessariamente dos outros, diz Halbwachs. Logo, é com base na ideia de coletividade que

${ }^{2}$ Em oposição à total abertura da potencialidade verbal da estruturação poética da história, é necessária de acordo com Ricoeur, que "certa arbitrariedade tropológica não faça esquecer a espécie de pressão que o acontecimento passado exerce sobre o discurso histórico por meio de documentos conhecidos, exigindo dele uma retificação sem fim." (1997, p. 259). 
se desenvolvem as memórias individuais. Desta forma, as primeiras lembranças são aquelas compartilhadas. São as lembranças comuns que nos possibilitam afirmar que jamais estamos sós. Para Halbwachs,

a rememoração pessoal está situada na encruzilhada das redes de solidariedades múltiplas em que estamos envolvidos. Nada escapa à trama sincrônica da existência social atual, é da combinação desses diversos elementos que pode emergir aquela forma que chamamos lembrança, porque a traduzimos em uma linguagem. Assim, a consciência jamais está encerrada em si mesma, não é vazia nem solitária. Somos arrastados em inúmeras direções, como se lembrança fosse uma baliza que permitisse nos situarmos em meio da variação constante dos contextos sociais e da experiência coletiva histórica (2003, p.13).

A episteme histórica é assinalada pela operação historiográfica. Predominam múltiplas fases a começar pelo testemunho como prática para tal operação, culminando nas análises arquivísticas em que há uma permanente interrogação aos documentos erigidos ao longo do tempo. Segue com a construção de arquivos, passando pela explicação e compreensão dos fenômenos arquivados. A fase final é constituída pela escrita. Segundo Ricoeur, a história é desde o começo até o fim escrita. Neste caso, os arquivos fundam a primeira escrita com a qual a história se depara, antes da própria história se transformar em possibilidade literária. Todavia, é difícil estabelecer um começo para o pensar histórico, uma vez que esse, quando compreendido com uma temporalização da experiência comum, torna-se indefinível. Recorrendo a Gramatologia, de Jacques Derrida, Ricoeur escreve: "os homens espaçaram seus signos, ao mesmo tempo - se isto tem algum sentido - em que os encadearam ao longo da continuidade temporal do fluxo verbal" (2007, p. 149). E por isso a impossibilidade de se encontrar o início da escrita da história. Nesse sentido, a história não cessa de "nascer do distanciamento em que se embasa o recurso para exterioridade do rastro arquival" (2007, p. 149-150).
A obra de E. Lévinas igualmente procura responder às catástrofes, apelando à metáfora do Rosto como categoria singular em direção ao reconhecimento radical ao outro, implicando em responsabilidades mútuas. "Esta apresentação do (Rosto) é a não-violência por excelência, pois em lugar de ferir minha liberdade, ela a chama à responsabilidade e a instaura. Ela é a paz, a condição de todo o ensinamento" (LÉVINAS, 2008, p.175). Em Totalidade e infinito, Lévinas inicia com um questionamento temeroso: "A lucidez - abertura de espírito ao verdadeiro - não consiste em entrever a possibilidade permanente da guerra?" (2008, p. 07). Diante das atrocidades, Lévinas parece se perguntar a todo o momento como ser correto sem ser tomado pela ingenuidade, uma vez que o estado de guerra suspende a moral, despojando as "instituições e as obrigações eternas da sua eternidade" e, por conseguinte, anulando os "imperativos incondicionais" (2008, p.07). A guerra projeta antecipadamente "sua sombra sobre os actos dos homens" (2008, p. 07).

Com base na ideia de uma era marcada pela catástrofe e genocídios, Márcio Seligmann-Silva discorre sobre a importância do testemunho. ${ }^{3}$ Para estudioso, o testemunho deve ser compreendido tanto no seu sentido jurídico e de testemunho histórico como também no sentido de 'sobreviver', "de ter-se passado por um evento-limite, radical, passagem essa que foi também um atravessar a morte, que problematiza a relação entre a linguagem e o real" (2003, p.08).

${ }^{3}$ Segundo Jaime Ginzburg, o conceito de testemunho "tem ganhado espaço nos últimos anos nos estudos literários brasileiros", podendo ser encontrado em "investigações sobre temas hispano-americanos, africanos e alemães" (2012, p. 52). 0 campo do testemunho tem crescido em torno do debate sobre as relações entre escrita e exclusão. Ginzburg afirma que o debate crítico sobre testemunho e literatura inclui desde posições amplamente favoráveis à valorização do testemunho, assim como ponderações inclui desde posições amplamente favoráveis à valorização do testemunho, assim como ponderações incisivas, como a de Beatriz Sarlo. Ao se falar em testemunho, Ginzburg destaca para "uma perspectiva que associa o debate entre a escrita à reflexão sobre exclusão social" (2012, p. 52). Nesse sentido, os discursos críticos, adverte o estudioso, que apontam para "separaçóes rígidas entre literatura e história podem ser rediscutidos em razão de uma integração necessária que o testemunho, como testeme de 
Nesse sentido, o testemunho ou teor testemunhal, como quer o autor, é o mecanismo narrativo essencial para se pensar a realidade e, simultaneamente, os limites da representação, em especial a literária, problematizando o dizer e o dito a partir de uma perspectiva traumática que colocaria em questão o texto realista e os chamados textos pós-modernos. Seligmann-Silva escreve: "Falamos também de um teor testemunhal da literatura de um modo geral que se torna mais explícito nas obras nascidas de ou que tem por tema eventos-limites" (2003, p.08). Tal real requer uma nova ética da representação, na medida em que não se satisfaz "nem com o positivismo inocente que acredita na possibilidade de se dar conta do passado, nem com o relativismo inconsequente que quer resolver a questão de representação eliminando o real" (2003. p.10). A reflexão sobre o testemunho conduz a problematização da divisão fixa entre o discurso dito denotativo-representativo e o dito literário. Todavia, não aceita o apagamento das fronteiras.

O conceito de teor testemunhal não deve apagar ou reduzir a preocupação com o estudo das estratégias "estético-poetológicas" que impregnam toda a manifestação escrita. Um estudo que leva em conta o teor testemunhal deve, no entanto, conduzir a uma nova interpretação desses componentes. Com base nessas disposições, Seligmann-Silva defende que "toda a obra de arte, em suma, pode e deve ser lida como um testemunho da barbárie" (2003. p. 12).

Ao mesmo tempo, Seligmann-Silva anuncia a necessidade de um diálogo íntimo da teoria do testemunho com a psicanálise. Nesse sentido, dois ensaios de Freud contribuem para o debate: Recordar, repetir e elaborar (1914) e Luto e melancolia (1915). O primeiro trata das resistências que impedem que acontecimentos traumáticos do passado sejam trazidos ao consciente, ficando recalcados no inconsciente. De acordo com Freud, o inconsciente se pauta pela não verbalização, fazendo com que seu conteúdo não seja narrado. Ao invés disso, surgem "mecanismos de substituição/transferência" que mascara de maneiras distintas o retorno do recalcado como, por exemplo, a “compulsão de repetição". O sujeito não reproduz o fato esquecido em forma de lembrança, mas em forma de ação, repetindo tal ação sem saber que o faz. Esse processo é uma maneira de resistência à conscientização do acontecimento traumático (FREUD, 1969, v. XII, p. 196-197).

O "trabalho de elaboração" da resistência entraria como mecanismo importante na reconciliação do sujeito com o objeto recalcado vivido no passado. O intuito da elaboração é descobrir os impulsos instintuais reprimidos que alimentam a resistência. Tal trabalho pode ser definido como a busca do sujeito em direção ao núcleo indestrutível do passado vivido, agora alcançado através da lembrança.

Em Luto e melancolia, o ponto de partida é uma perda significativa. Perda essa que conduz o sujeito a um superinvestimento na representação do objeto perdido, numa tentativa de mantê-lo vivo. Duas linhas de ação decorrem dessa situação. A primeira seria a realização do luto, "presumido como diretamente acessível, pelo menos num primeiro momento" (RICOEUR, 2007, p. 85). A segunda linha, consequência do fracasso da primeira, seria a impossibilidade de abandono do investimento no objeto perdido, levando o sujeito à melancolia. 0 trabalho de luto, para Freud, é realizado quando, não existindo mais o objeto amado, a libido é retirada do mesmo, afastando qualquer ligação entre ambos. Todavia, o abandono de uma posição libidinal não se constitui em tarefa fácil, nem mesmo quando da já apresentação de um substituto. É necessário grande dispêndio de tempo e energia catexial ${ }^{4}$, prolongando-se psiquicamente, nesse meio tempo, a existência do objeto perdido. Todavia, quando da conclusão do trabalho de luto, o sujeito fica livre e desimpedido novamente.

${ }^{4}$ Segundo Freud, catexia é o processo por meio do qual a energia libidinal contida na psique é relacionada ou aplicada na representação mental de um indivíduo, coisa ou ideia. 
Em relação à melancolia, Freud diz que a perda pode conter uma natureza mais ideal, isto é, talvez não seja possível averiguar o que foi perdido. De acordo com Freud, "melancolia está de alguma forma relacionada a uma perda objetal retirada da consciência, em contraposição ao luto, no qual nada existe de inconsciente a respeito da perda". Segundo o autor, "no luto, é o mundo que se torna vazio; na melancolia é o próprio ego" (FREUD, 1969, V. XIV, p. 278).

Os dois ensaios de Freud servem de apoio a Ricoeur ao aproximar tais categorias à natureza e função da história e da memória. De acordo com o filósofo francês, "a história encarrega-se dos mortos de antigamente", assim a operação histórica pode ser considerada como "um ato de sepultamento", isto é, um "ato renovado de sepultamento". Daí que tal "sepultura escriturária prolonga no plano da história o trabalho da memória e o trabalho de luto" (2007, p. 506). Desta forma, o trabalho de luto separaria definitivamente o passado do presente, abrindo espaço para o futuro.

Num olhar preliminar é o que se percebe em Eu sou a Árvore (2016), de Possidônio Cachapa, A última canção da noite (2013), de Francisco Camacho, e Combateremos a sombra (2007), de Lídia Jorge, os três romances tomados por testemunhos traumáticos.

Estruturado em três partes, Eu sou a Árvore, romance de Possidônio Cachapa $^{5}$, concentra sua atenção narrativa em torno de uma família

\footnotetext{
${ }^{5}$ Após a infância em Évora, muda-se para os Açores, período que inspirou o seu romance O Mar Por Cima. O seu romance mais conhecido, Materna Doçura, conta a história de Sacha G. que perde a mãe, de forma trágica, antes de conseguir resolver a sua atração edípica e que, por isso, a busca contínua a procurar no corpo de todas as outras mulheres. No romance Rio da Glória, a história se desenvolve em torno de duas personagens que atravessam o Brasil em busca de respostas às suas questões internas, numa reflexão sobre a condição humana, as práticas religiosas e a busca do sucesso fácil. Em 2009, publica $O$ Mundo Branco do Rapaz Coelho. Em 2015, revisa o romance Viagem ao Coração dos Pássaros, criando a versão definitiva do texto. Desenvolve ainda trabalho como argumentista e realizador de curtas e longas metragens. 0 seu último filme foi "O Nylon da Minha Aldeia", adaptado a partir da novela do mesmo nome. Obras do autor: Nylon da Minha Aldeia (novela), 1997; Materna Doçura (romance), 1998; mesmo nome. Obras do autor: Nylon da Minha Aldeia (novela), 1997; Materna Doçura (romance), 1998; Viagem ao Coração dos Pássaros (romance), 1999; Assírio \& Alvim/versão revista, ed. Marcador, 2015; Shalom (teatro), 2001; O Mar por Cima (romance), 2002; Segura-te ao Meu Peito em Chamas (contos), infantil), 2007; O Mundo Branco do Rapaz Coelho (romance), 2009.
}

portuguesa assinalada por acontecimentos traumáticos. Estes derivam do relacionamento, em parte, do casal Samuel e Judite, conhecida com Jude. Jovens, se conhecem na década de 1960, numa Lisboa dominada pelo salazarismo e a chamada contracultura. Contrariando aos pais, casam-se. Em seguida, Jude engravida, passando a cuidar dos filhos Laura e Esperanto. Descontente com a vida na cidade, Samuel parte para o campo. Justifica a mudança ao concluir que o espaço urbano é nefasto à educação das crianças. A mudança provoca na esposa desalento. Judite segue insatisfeita. As crianças crescem, cursam a escola local, atraindo a atenção dos colegas em virtude de hábitos e de comportamentos distintos. Uma produção agrícola distinta à praticada pelos vizinhos é o caminho adotado por Samuel. A atual situação complica-se com o nascimento de Vitória, terceira filha do casal, que dissemina nova crise familiar. Samuel mostra-se cada vez mais ausente e arredio, interessando-se apenas pelo trabalho, enquanto Jude se vê presa exclusivamente ao atendimento dos filhos. O distanciamento dos pais reflete-se no comportamento de Vitória que cresce cheia de temores, mantendo-se num estado de reclusão e silêncio.

Eu sou a Árvore explicita a incapacidade dos pais em comunicar-se com os filhos. Um dos episódios reveladores dessa inoperância é o assassinato de Mário, namorado de Laura na adolescência. $O$ crime choca. É a menina Vitória que, com menos de dez anos de idade, causa a morte de Mário. ${ }^{6}$ Na sua imaginação infantil, acredita que Laura está sendo agredida pelo namorado quando estes fazem amor num local ermo. $\mathrm{O}$ crime ocorre quando a família se encontra em férias numa praia portuguesa. Laura e Mário se encontram diariamente. Sem que familiar algum perceba, da sacada do

6 No romance de estreia, intitulado Materna doçura (1999), a personagem Sacha G., aproximadamente com dez anos de idade, assassina o marido de sua mãe. 
apartamento, Vitória vigia as saídas do casal à distância. Numa quebra narrativa surpreendente, lê-se: "Vitória ainda tinha mais duas pedras na mão quando da cabeça esmagada de Mário começou a engrossar o jorro de sangue." (p. 73) Em desespero, Laura pede à menina que chame o pai. Vitória traz Esperanto que, juntamente com Laura, enterraram o rapaz nas dunas. Tal segredo se estenderá ao longo do romance, jamais sendo esclarecido. Os filhos de Samuel e Jude crescem, partem de casa, vivendo em diferentes lugares. A notícia do suicídio de Vitória abate profundamente a família. No enterro,

Jude viu a filha descer à terra num caixão branco de virgem. Levava nas mãos um ramo de flores silvestres que alguém se lembrara de apanhar e que já estava murcho, como se tivesse pressa em secar. Na cabeça que lhe taparam antes de cobrir com cal ia uma coroa de rosas quase vermelhas. Essas, sabia-se de quem tinham vindo: de Laura, que as colhera nas traseiras da casa e as entrelaçara, uma a uma, espetando os espinhos nos dedos enquanto o fazia. Agora mesmo, enquanto a urna desce debaixo do olhar de Jude, os seus dedos continuam rasgados, mesmo se não lhe sente a dor. A dor de Laura está espalhada do peito até o topo da cabeça; paralisa-a como se tivesse sido atingida por raios de pistolas marcianas e tudo nela se movesse a custo. Jude viu a filha descer à terra num caixão branco de virgem e seus joelhos dobraram-se. Ninguém a segurou e os ossos que bateram no solo em volta da sepultura esmagaram-lhe a pele por dentro. Não era apenas uma filha que morria verdadeiramente para ela. Era o seu remorso, que subia daquela terra estéril, por não a ter amado com tanto intensidade como achava que deveria. Um fantasma em forma de dor. Vitória nascia-lhe de novo, mas agora por dentro de todo o corpo. No interior da pele. Como uma doença que a consumiria, com mais ou menos intensidade, para sempre (2016, p. 237-8).

A morte da filha faz com que Jude desapareça, sem deixar rastro algum. Samuel mergulha numa profunda depressão. Os irmãos retomam suas vidas, rememorando aquela trágica tarde que, numa praia deserta em
Portugal, Vitória com menos de dez anos de idade espedaçara a cabeça de um jovem. A visita dos filhos a Samuel dá fim ao livro. Laura está casada com um brasileiro que conhecera em Londres. Possuem dois filhos. Esperanto apresenta seu namorado, motivo de discussões e desentendimentos com o pai. Em meio ao reencontro, Samuel lê uma carta da esposa que vive um novo relacionamento em Durban, África do Sul.

Embora o romance discorra essencialmente sobre conflitos familiares, há passagens em que a história do século $\mathrm{XX}$ vem à tona. A violência do regime salazarista sobre aqueles que lutavam pela transformação social e pela democracia em Portugal está representada nas personagens Casaca e Marcelino. Tais passagens não se coadunam com a trama central do livro. No entanto, se justificam ao trazer o passado português. O cadáver de Mário oferece-se, estruturalmente, para trazer a tortura empregada pelo regime salazarista. Casaca e Marcelino são colegas de infância. Estudam na mesma escola. Adultos, seguem caminhos diferentes. Casaca torna-se um agente da PIDE, a polícia política de Salazar. O filho de Marcelino é preso e torturado pelo policial, vindo a falecer nas prisões da ditadura. Marcelino, então, inicia uma longa travessia para descobrir o responsável, chegando ao nome do ex-colega de aula. Aposentado, vivendo na praia, Casaca sente saudades do passado. Crê que o país, hoje, está entregue aos comunistas, levando a nação à ruína e à falta de valores. Acredita que quando cogumelos crescem em certos terrenos é porque ali há algo a ser investigado. Na concepção da personagem, indicam a presença de cadáveres enterrados. Ao deparar-se com tais plantas, dirige-se ao local, encontrando os restos de Mário em adiantado estado de putrefação. Marcelino, desde que descobrira a morada de Casaca, persegue-o para vingar o desaparecimento do filho. Ao ver o ex-Pide retirar um corpo da areia, acreditando ser seu filho, Marcelino acerta-lhe um golpe de pá, assassinando-o. Vingado o filho, Marcelino se suicida. 
O romance $A$ última canção da noite (2013), do escritor português Francisco $\mathrm{Camacho}^{7}$, centra-se na personagem Jack Novak, guitarrista e letrista da banda The Bitters, grupo de sucesso mundial. Novak decide afastar-se subitamente da cena musical, causando um impacto no meio social e artístico. Sem deixar rastros, evitando explicações e motivos, some, rumando em direção ignorada. Esse é o elemento que dá partida à história, provocando, no leitor, questionamentos acerca do desaparecimento. Ao final do livro, pode-se dizer que são múltiplas as razões que fizeram com que Jack Novak, ídolo do rock internacional, abandonasse a carreira em seu auge.

Jack Novak é acompanhado por outra personagem igualmente significativa: David Almódovar, crítico musical português que conhece profundamente a música e a trajetória da banda The Bitters. David vê-se envolvido em trama que lhe causa a perda do emprego. Crítico implacável, é acusado de plágio, fato que lhe custa a demissão do jornal e da empresa de publicidade em que atua.

Ao final da narrativa, o encontro do músico com o crítico desencadeia, pode se dizer, a recuperação de ambas as personagens. Ao reaparecer na casa do produtor musical Victor Capri, Jack pede ao amigo que lhe apresente o crítico David, para a surpresa de Capri. O motivo é um texto que o jornalista publicara quando do lançamento do disco Desert Flowers que causara impressão ao guitarrista. 0 texto escrito expõe aspectos que mexem com Novak. Ali há sugestões que o levam a refletir acerca do passado e sua relação familiar. A resenha crítica opera uma reflexão que ultrapassa o

7 Francisco Camacho nasceu no Funchal em 1969. Foi redator e editor do semanário $O$ Independente redator e diretor-adjunto da revista Grande Reportagem, diretor das revistas Volta ao Mundo e NS editor-executivo da revista Sábado e diretor-adjunto do jornal i. Recebeu o Prémio Revelação do Clube Português de Imprensa (1993) com uma reportagem na Escócia e o Prémio Fernando Pessoa de Jornalismo (1998) com uma reportagem em Moçambique. Em 2010, trocou o jornalismo Pela de Jornalismo (1998) com uma reportagem em Moçambique. Em 2010, trocou o jornalismo pela edição de livros. Atualmente, é editor da Oficina do Livro e escreve regularmente nas revistas Sábado e GQ. Niassa, o romance com que se estreou, foi distinguido com o Prémio PEN Clube na categoria Primeira Obra, em 2008, e recebeu vários elogios da crítica. A Última Canção da Noite e o seu segundo prodígio técnico e musical da banda, tornando-se inesquecível para Novak. Além de elogios, vinculando a banda a intersecções do rock do passado e do presente, num acabamento intertextual original, David escreve:

Esta música que aconchegamos junto ao coração nos piores e melhores momentos de nossa vida descende de uma dor profunda, mas de tal modo mascarada que só um punhado de seguidores atentos dos Bitters a conseguirá pressentir. A fonte dessa dor permanece um mistério. Uma vez que Novak insiste em apresentar-se como alguém livre de traumas e tormentos, é bem possível que nunca ninguém venha a identificá-la. Por respeito à vontade do grande mestre, talvez seja melhor deixar as coisas assim, entregues à doce ilusão de que Jack Novak é apenas um homem vulgar, com uma história relativamente vulgar, que, por obra e graça de um deus desconhecido, produz a música popular mais extraordinária desde Lennon e MaCartney (2013, p.120).

O retorno a ser um homem comum sem que esteja sob o alvo da publicidade e dos meios de comunicação parece ser o desejo de Novak, levando-o ao afastamento dos compromissos impostos pelo sucesso. 0 músico sente-se cansado da vida movida à luz dos holofotes, entregue a uma agenda contínua de shows e do assédio permanente de fãs e imprensa. Em conversa com David, confessa que almeja uma existência vulgar.

Há outros aspectos que conduzem a personagem a refazer sua vida. O impacto da guerra étnica nos Balcãs no início dos anos 1990 do século XX é um deles. Novak reafirma a todo instante quando questionado em entrevistas que não possui vínculo algum com o passado daquela região, particularmente na Croácia. Todavia, tais raízes estão presentes na família. Seu pai nascera na Croácia, atuando mais tarde como diplomata em Londres, cidade natal do filho músico. É por meio dessa relação que a guerra nos Balcãs assume contornos dramáticos na existência de Novak. Suas constantes negativas não evitam que os sonhos e pesadelos de tal genocídio reapareçam, mostrando seu laço com aquele espaço. 
A figura da mãe contribui igualmente para a formação de Novak. Natural de Inverness, na Escócia, AmberReid ama a música, procurando exercê-la como violista. Casara com Dragan Novak, adido cultural na embaixada da Iugoslávia. Amber almeja viver no mediterrâneo, particularmente no Sul de Portugal. Sonha com tal experiência desde o dia em que fora levada ainda criança pelos pais àquela região. Dragan gosta da vida londrina, mas cede aos desejos da esposa, conseguindo sua transferência para Lisboa.

Depois de um período de euforia, aos poucos a vida em Portugal começa a se tornar cansativa. Amber passa a ter constantes crises, sofrendo oscilações de humor, afetando o convívio familiar. Por sua vez, o pai de Novak conforma-se com o abismo que separa a capital portuguesa da exuberância artística e cultural de Londres.

Em meio aos conflitos políticos e pessoais, Novak descobre, num exame médico de rotina, uma grave doença. Tal notícia impulsiona o artista a retornar, reencontrando conhecidos. A intenção é escrever um testemunho acerca da sua existência, mostrando a história recente dos conflitos étnicos nos Balcãs, bem como a importância da memória familiar na constituição de sua identidade. Assim, os traumas provocados pelos genocídios no leste europeu alicerçam as discussões do romance, bem como a importância do território português no engendramento identitário da personagem.

O romance Combateremos a sombra (2007), de Lídia Jorge, trata igualmente de vidas traumatizadas ${ }^{8}$. Tal condição é revista por rememorações

\footnotetext{
${ }^{8}$ No ensaio Literatura e trauma: um novo paradigma, Márcio Seligmann-Silva elabora sua reflexão sobre o tema a partir do estudo $O$ desenvolvimento da teoria do trauma na psicanálise do estudioso alemão Werner Bohleber. De acordo com Seligmann-Silva, para Bohleber, a discussão em torno do trauma parte de uma necessidade histórica que determinou o nascimento e o desenvolvimento de tal teoria. Segundo Bohleber: "As catástrofes do século passado [XX], bem como as do que se inicia, como guerras, Holocausto, perseguição catástrofes ho herseguição à visên rénação as da psicanálise" (SELIGMANN-SILVA, 2005, p.63)
}

em torno de um amplo painel social, assinalados pela memória. $\mathrm{Na}$ narrativa de Lídia Jorge, tal como a de Lobo Antunes, o testemunho das personagens ganha dimensões coletivas. As ações clínicas do luto e da melancolia adquirem uma perspectiva histórica, descortinando um universo disseminador da violência traumática. Emblemático, neste sentido, é o episódio do angolano Lázaro Catembe. Trata-se de uma das passagens mais comoventes da narrativa. O que acontece é que Catembe não "reconhece" - são invisíveis - os seus compatriotas africanos negros quando estes estão conduzindo os coletivos públicos nas ruas de Lisboa. Logo, evita em apanhá-los, aguardando outro coletivo que não seja conduzido por um conterrâneo. No entanto, a linha percorrida do centro ao bairro é feita pelo mesmo condutor, impedindo Catembe de utilizar o ônibus. A personagem traduz do seguinte modo a experiência traumática da guerra:

Era mesmo o fim da linha. Ambos iam descer pela porta da frente, e Osvaldo fez questão de dizer umas quantas palavras ao condutor. Falaram durante três segundos a propósito da chuva. Lázaro Catembe, com a testa coberta de suor, ali junto, a ouvir. Depois tinham descido. Tinham parado. Osvaldo Campos não iria dizer uma palavra sobre o percurso, seria um erro se o fizesse, coisa simples que fosse. Só faltava despedir-se de Lázaro, que estava de novo sobre o passeio, a olhar para as traseiras do autocarro que se afastava agora em sentido inverso, com a mulherzinha solitária, sentada à janela. Lázaro via a viatura afasta-se e continuava coberto de suor. 'Aquele cabrom está vivo, doutor! Aquele grande cabrom!' Lázaro tremia, abriu a pasta e retirou um lenço, sacudiu-o e em vez de o levar às narinas, colocou-o sobre a cabeça e chorou de rosto aberto, sentado sobre o lancil. A chuva ainda estava suspensa sobre o horizonte talhado de casinhas baixas. Lázaro chorava. 'Desculpe, doutor...' Chorava por aquele cabrom que na guerra de Luanda, em 92, conduzia um autocarro cheio de gente, e se tinha deixado matar. Deveria ser a duodécima vez que Lázaro contava, mas era a primeira que o fazia daquele modo - 'Senhor, eu vinha sentado na frente, aquele condutor caiu para cima de mim, o sangue dele borrifou a janela toda, borrifou a mim todo, e o carro andou sozinho, sem direçom, com o condutor emborcado em cima do meu peito, o volante sozinho, e o autocarro a estampar-se na esquina do Tribunal, 
com um estrondo. Buuung! Ele morto e eu vivo, todos os outros a fugirem do autocarro, todos menos Lázaro Catembe que tinha no colo o condutor, e mais quatro também não fugiram, eles estavam no mesmo estado do condutor, encostados aos vidros. Éramos seis lá dentro, Senhor, só eu me mexia no meio deles, uns sentados nos seus lugares, outros nom, e depois deixei de ouvir e ver. Não me lembro, fiquei lá dentro com eles de manhã, em Luanda, minha terra de recordaçom... (2007, p.330).

O depoimento de Catembe nos traz novamente a importância do testemunho, bem como aos conceitos de trauma observados pela psicanálise. Aqui tais acontecimentos ganham um teor histórico fundamental, contrapondo-se a passagens em que Freud localiza a situação traumática nos primeiro anos de vida da criança ${ }^{9}$. Com o advento da Primeira Guerra, o autor refaz tal posição ao observar os transtornos desenvolvidos pelos soldados que retornavam dos campos de batalha. Num conhecido texto, Walter Benjamin escreve: "No final da guerra, observou-se que os combatentes voltavam mudos do campo de batalha não mais ricos, e sim mais pobres em experiência comunicacional” (1985, p.198).

Para combater aquilo que Ricoeur denomina de a "memória impedida" é central a recordação de lembranças traumáticas. O paciente sente-se impossibilitado de reproduzir o fato esquecido em forma de lembrança.

\footnotetext{
${ }_{9}^{9}$ Em Moisés e o monoteísmo (1997), Freud denomina como trauma "aquelas impressões, cedo experimentadas e mais tarde esquecidas", a que concede grande importância na "etiologia das neuroses". De acordo com pesquisas, Freud diz que "aquilo que chamamos de fenômenos (sintomas) de uma neurose são o resultado de certas experiências e impressões que encaramos como traumas etiológicos" (1997, p.66). Os traumas ocorrem na primeira infância até aproximadamente o quinto ano de idade. As experiências são totalmente esquecidas, não sendo acessíveis à memória. Incidem, segundo o estudioso, "dentro de período de amnésia infantil, geralmente interrompida por alguns resíduos mnêmicos isolados, conhecidos como recordações (ou lembranças) encobridoras" (1997, p. 66). Para Freud, tais experiências estão relacionadas a impressões de "natureza sexual e agressiva" e também a "danos precoces ao ego" (mortificações narcísicas). Em outras obras, Freud igualmente trata das questões envolvendo os sintomas traumáticos. Dentre elas, destacam-se Além do princípio de prazer Compêndio da Psicanálise. Pode-se resumir que o Dentre elas, destacam-se Além do princípio de prazer, Compera associa a um imprevisto. O choque causado pe a de de dúvidas e temores.
}

Ricoeur reconhece que a palavra chave para tal processo é trabalho de rememoração, contra a compulsão à repetição. As formulações de Freud e Ricoeur servem para levantar hipóteses acerca da "memória impedida" em que se pode verificar que os fatos referentes aos romances aqui analisados permanecem recalcados no subconsciente de algumas personagens, as quais não conseguem se lembrar dos acontecimentos vividos no passado. Ricoeur chama isso de "uma forma ardilosa de esquecimento, resultante do desapossamento dos atores sociais de seu poder originário de narrarem a si mesmos" (RICOEUR, 2007, p. 455). O mesmo autor adverte, porém:

Mas esse desapossamento não existe sem uma cumplicidade secreta, que faz do esquecimento um comportamento semipassivo e semi-ativo, como se vê no esquecimento de fuga, expressão da má-fé, e sua estratégia de evitação motivada por uma obscura vontade de não se informar, de não investigar o mal cometido pelo meio que cerca o cidadão, em suma por um querer-não-saber (RICOEUR, 2007, p. 455, grifo nosso).

Essa ordem passa pelo que Freud chama de "mecanismo da censura", ou seja, encontra-se na região das lembranças cujo acesso é proibido, censuradas pela barreira do recalque, e isso deve ser tratado, segundo o mesmo autor, não como um acontecimento do passado, mas como uma força atual (FREUD, 1969, p.198). Ademais, depreende-se, no caso da memória individual, que é mais significativo dar atenção aos esquecimentos do que às lembranças. Aplicando tal reflexão no âmbito de uma sociedade, grande importância deve ser dada àquilo que ela tenta ocultar ou mascarar de seu passado.

Após a leitura das narrativas, notam-se as preocupações dos autores com traumas familiares e coletivos, provocados pela presença de conflitos históricos, políticos e identitários. Nesse sentido, é importante a contribuição de Paul Ricoeur e as reflexões advindas da psicanálise. A leitura dos três romances nos conduz outra vez às interrogações epistemológicas 
de Ricoeur. O filósofo francês discute as aporias da memória, referindose a duas tradições. Uma delas intitula de tradição do olhar interior, cujo postulado é compreender o funcionamento da mente a partir de suas propriedades ontológicas que garantiriam aos sujeitos, no plano individual, a capacidade de recordar e lembrar. Neste caso, recorre a três autores: Santo Agostinho, John Locke e Husserl. Apoiado na fenomenologia husserliana, o filósofo chama a atenção para a consciência íntima do tempo, expressão que traduz e revela a individuação das coisas vividas através das lembranças.

De outro modo, em campo contrário, apoiando-se na sociologia, traz o estudo Memória coletiva, de Maurice Halbwachs, enfatizando a memória como fenômeno social coletivo. Em meio à exposição, Ricoeur propõe pensar a categoria os "próximos". Estes seriam uma categoria intermediária que operaria concretamente as trocas vivas das pessoas individuais e da memória pública das comunidades. Segundo Ricoeur,

os próximos, essas pessoas que contam para nós e para os quais contamos, estão situados numa faixa de variação das distâncias na relação entre si e os outros. A proximidade seria a réplica da amizade, dessa philia, celebrada pelos Antigos, a meio caminho entre o indivíduo solitário e o cidadão definido pela sua contribuição à politeia, à vida e à ação da polis (2007, p. 141).

A todo instante, Ricoeur interroga sobre as possibilidades de aproximação dos discursos da fenomenologia e da sociologia, demonstrando, ora a independência, ora a ligação dos mesmos.

Também o discurso psicanalítico estaria calcado não apenas no indivíduo e seus dramas familiares, mas igualmente ao conhecimento histórico, emanado de memórias coletivas que deslindariam os traumas vividos pelos sujeitos. Ricoeur faz uma releitura de dois ensaios importantes de Freud para discutir tal questão. 0 primeiro é Recordar, repetir e elaborar e o segundo é Luto e melancolia. A ideia é mostrar que, muitas vezes, os traumas históricos são responsáveis pela situação vivida pelo individuo. 0 trabalho de luto é um exercício de rememoração que, muitas vezes, exige do analista uma postura que vai além das categorias que embasam determinado conhecimento disciplinar.

Desta forma, a relação entre memória individual e coletiva atravessa boa parte do debate realizado por Paul Ricoeur, tomando de empréstimo autores de diferentes tradições com a finalidade de compreender os sujeitos em sua totalidade interior e exterior. Os traumas históricos atingem toda uma coletividade, ecoando individualmente em cada sujeito sobrevivente. Em relação aos romances investigados, tal propósito ocorre nos dois sentidos. Se por um lado, há personagens atrelados a dramas pessoais, em visível projeção familiar, de outro, as feridas existentes são decorrentes do universo histórico. É o que se percebe em Eu sou a árvore, A última canção da noite e Combateremos a sombra.

\section{Referências}

BENJAMIN, Walter. Magia e técnica, arte e política: ensaios sobre literatura e história da cultura. São Paulo: Brasiliense, 1985.

CAMACHO, Francisco. A última canção da noite. Lisboa: Dom Quixote, 2013.

CACHAPA, Possidônio. Eu sou a árvore. Lisboa: Companhia das Letras, 2017.

DERRIDA, Jacques. Os espectros de Marx. Rio de Janeiro: Relume-Dumará, 1994.

FREUD, Sigmund. Recordar, repetir, elaborar. In: FREUD, S. Edição standard brasileira das obras psicológicas completas de Sigmund Freud. Rio de Janeiro: Imago, v. XII, 1969.

FREUD, Sigmund. Luto e melancolia. In: FREUD, S. Edição standard brasileira das obras psicológicas completas de Sigmund Freud. Rio de Janeiro: Imago, v. XIV, 1969.

FREUD, Sigmund. Moisés e o monoteísmo. Rio de Janeiro: Imago, 1997.

HALBWACHS, Maurice. A memória coletiva. São Paulo: Centauro, 2003.

GINZBURG, Jaime. Linguagem e trauma na escrita do testemunho. In: GINZBURG, J. Crítica em tempos de violência. São Paulo: Edusp, 2012. 
JORGE, Lídia. Combateremos a sombra. Lisboa: Dom Quixote, 2007.

LÉVINAS, Emmanuel. Totalidade e infinito. Lisboa: Edições 70, 2008.

RICOEUR, Paul. A memória, a história, o esquecimento. Campinas; SP: Unicamp, 2007.

RICOEUR, Paul. Tempo e narrativa. São Paulo; Campinas: Papirus, 1997.

SELIGMANN-SILVA, Márcio (Org.). História, memória, literatura: o testemunho na era da catástrofe. Campinas; SP: Unicamp, 2003.

SELIGMANN-SILVA, Márcio. Literatura e trauma: um novo paradigma. In: SELIGMANN-

SILVA, M. O local da diferença: ensaios sobre memória, arte, literatura e tradução. São

Paulo: Editora 34, 2005.

Recebido em 29/06/2018

Aceito em 13/09/2018. 